\title{
Self-Determination to Fight Oppressions as Seen in the Main Character of The Color Purple by Alice Walker
}

\author{
Levita Setya Budi \& Dewi Widyastuti \\ iralevita@gmail.com \&ewi@usd.ac.id \\ Department of English Letters, Universitas Sanata Dharma
}

\begin{abstract}
In several cultures in the world, women usually receive inequality and experience oppression. These experiences are reflected in a literary work by Alice Walker entitled The Color Purple. This novel tells about a woman, named Celie, who is oppressed. However, she fights the oppression by having her self-determination. This study tries to identify how the characteristics of Celie are described, to find out how the oppressions that she experiences are described, and to examine how her self-determination to fight the oppressions are described.

The Color Purple proves that self-determination helps women to fight oppression whatever characteristic that they have. Celie is described as an uneducated, submissive, and unattractive woman in the story. She experiences sexual oppressions and non-sexual oppression. She proves that her sexual self-determination, by having a lesbian relationship with Shug, and non-sexual selfdetermination, leaving her husband to Memphis and running her own business, helps her to fight oppressions that she experiences, and she could live her life without any oppression. Feminist approach and radical feminism theory were used in this study to analyze self-determination to fight oppression of the main character of The Color Purple.
\end{abstract}

Keywords: self-determination, oppression, women

\section{Introduction}

In several cultures in the world, women are usually treated differently from men. They always experience inequality because they are considered lower than men. Women were not able to enjoy the rights that men had. It happens because of the patriarchal culture. In patriarchy, men were the center of everything. Only men that had the rights and authorities at home in patriarchal society (Madsen, 2000: xii).

Susan Brownmillershares the idea that men use oppression as a strategy for sustaining patriarchy. She also shares the radical position that all women constitute a single class with the same experience of oppression. One example of oppression here is rape. All women are victimised by rape because the threat of rape is directed to all women in patriarchal society.It is a way to dominate women in patriarchy because it benefits the men (Madsen, 2000: 12).

The domination of patriarchal society is the main concern of radical feminism that will be used in this study as they opposed the domination of patriarchal society, as stated here, "radical-libertarian feminists rejected patriarchal society's assumption there is a necessary connection between one's sex (male or female) and one's gender (masculine or feminine). Instead, they claimed that gender is separable from sex 
and that patriarchal society uses rigid gender roles to keep women passive ("affectionate, obedient, responsive to sympathy and approval" (Tong, 2009: 51).

According to Andrea Dworkin, there are three fundamental terms of radical feminism. First, women are the oppressed class and men are the class of oppressor in a patriarchal society. Second, their relationship is maintained through physical violence against women. Third, the oppression happens systematically under patriarchy (Madsen, 2000: 162).

Women, that are always being the victims of oppression, did not keep silent. They make many movements to struggle and fight for their rights throughout the history. One example of the movements is the three movements of American feminism. These movements show the self-determination that is done by women. Self-determination is a way that can be used by women to fight oppressions that they experience. The term self-determination according to Camille Paglia means, "What this means is that the individual should be granted the freedom to do anything that does not restrict the freedom of any other individual to do anything they wish" (Madsen, 2000: 24).

In this study, the writer uses The Color Purple by Alice Walker as the object of the study because the aim of this study is to reveal the self-determination to fight oppressions as seen in the main character of the novel, which is Celie. Celie is a fourteenyear-old girl that experienced oppression in her life. She is getting raped and abused by her stepfather. She is forced to marry a man that also abuses her. The oppressions that she experiences can be divided into two, which are sexual and non-sexual oppression. At the first of the story, she appears as a submissive woman. She never fights back; she just receives any oppression that she gets. However, at the end of the story, she is able to react and fight any oppression that she gets by using self-determination.

\section{Self-Determination}

Self-determination refers to characteristics of someone that leads someone to have freedom. By having freedom, they are able to make choices based on their own self. Women would be able to live without any oppression in their life. The term self-determination is described by Camille Paglia. According to her, self-determination means, "What this means is that the individual should be granted the freedom to do anything that does not restrict the freedom of any other individual to do anything they wish" (Madsen, 2000: 24).

Self-determination can be used as a way to fight oppression. This is in line with the role of radical feminism according to Andrea Dworkin. The role of radical feminism is to offer an accurate analysis of the condition of women who are angry with men that oppress them, to offer a means of women rage so they can properly direct to those who oppress them, and to point to a struggle that is based on self-determination (Madsen, 2000: 163).

Furthermore, for someone that has selfdetermination means taking some actions to fight an identity which he or she has received from society. For women that are oppressed, they have to become selfdetermining. They have to take action in order to fight against the oppression that they received, as stated here, "to become self-determining for a woman means taking some kind of action against an identity which she has received from her social conditioning-i.e., the identity of the socalled inferior sex," (Wandor, 1986: 134).

Radical feminism encourages women to be self-determining. Women have to be united and develop solidarity with each other. It asserts that women are strong and powerful, and not weak. It also declares that they refuse objectification and exploitation by men (Wardon, 1986: 135).

Radical feminists agree that patriarchal society oppresses women, as stated here that, "Socialist feminists agree with Marxist 
feminists that capitalism is the source of women's oppression, and with radical feminists that patriarchyis the source of women's oppression" (Tong, 2009: 4). Feminist states that being lesbian is a form of sexual self-determination because women want to release from the domination of patriarchy (Madsen, 2000: 226).

\section{Celie's Characteristics}

\section{Uneducated}

Celie, the main character in the story, is described as an uneducated woman. It can be inferred from her manner in writing her letters to God and her sister, Nettie. She writes her letters in a typical language of Black Americans. Her lacking of education happens because her stepfather never lets her go to school. For him, Celie is a dumb person, as stated in the story, "You too dumb to keep going to school, Pa say" (p. 11). Here, it can be seen that Celie's stepfather has a direct description that Celie is an uneducated woman; she is too dumb for him.

Celie's stepfather also thinks that Celie is not a clever woman. In the story, Celie's sister named Nettie is the one that should go to school. He says that Nettie is clever enough to go to school and Celie is not the clever one, as stated in Celie's letter, "The first time I got big Pa took me out of school. He never care that I love it. Nettie stood there at the gate holding tight to my hand. I was all dress for first day. You too dumb to keep going to school, Pa say. Nettie the clever one in this bunch" (p. 11). Here, it is clearly stated that Celie's stepfather sees Celie and her sister, Nettie, differently when he takes Celie out from school. He does not allow Celie to study. In his eyes, Celie is dumb and not the clever one, but her sister is the other way around.

Celie's stepfather considers that Celie has to do everything that a woman should do at home, not going to school. In the eyes of her stepfather, Celie is good to be a wife and keep children, not for going to school and get education. It can be seen from his conversation with Albert, Celie's husband, before they get married. Celie's stepfather says, "She ugly. Don't even look like she kin to Nettie. But she'll make the better wife. She ain't smart either, and I'll just be fair, you have to watch her or she'll give away everything you own. But she can work like a man," (p. 10).

Celie's stepfather convinces Albert to take Celie as his wife. Even though Celie is uneducated and different from Nettie, Celie can be a better wife. She can work like a man. For Celie's stepfather, Celie is also good with children, "She good with children" (p. 12).

\section{Submissive}

Celie is a submissive woman. She always obeys every word from her stepfather, her husband, and her stepchildren. She could not be mad every time she gets oppression from her stepfather. It can be seen from her speech; she says that a child has to obey her father and her mother because there is a norm written in the Bible that says so,

I can't even remember the last time I felt mad, I say. I used to git mad at my mammy cause she put a lot of work on me. Then I see how sick she is. Couldn't stay mad at her. Couldn't be mad at my daddy cause he my daddy. Bible say, Honor father and mother no matter what. Then after while every time I got mad, or start to feel mad, I got sick. Felt like throwing up. Terrible feeling. Then I start to feel nothing at all (p. 39).

The statement above gives an indirect presentation about Celie, it is clear that Celie is submissive. She knows what the Bible said and her reaction proves that she is submissive. She obeys the norm. She obeys her stepfather and never gets mad at him even though in her past life, her stepfather rapes her.

Celie's past life gives a significance proof that Celie is a submissive woman. When her stepfather gives a command to her, "You gonna do what your mammy wouldn't" ( $\mathrm{p}$. 3 ). This means that Celie has to satisfy her 
stepfather's sexual desire. It happens after Celie's mother getting sick and cannot satisfy his sexual desire. Celie's stepfather rapes her until she gets pregnant twice. However, Celie still never makes any protest toward any oppression that she experiences.

Celie is not only obeying what her father asks her to do but also her husband. Her husband is so cruel to her. He always asks Celie to do everything. If Celie does not obey him, he will beat her. This makes Celie fears him and never fights back. Instead of fighting back whenever her husband beats her, Celie just said, "I say, Just born that way, I reckon." (p. 22). She believes that everything that happens to her is a kind of fate. She thinks that she was born that way, so she has to receive it and becomes afraid of her husband.

For other characters, like Harpo, Nettie, Sofia, and Kate, all of them agree that Celie is very submissive. For Harpo, Celie's stepchildren, Celie is an obedient person because she always does whatever his father asks her to do and never refuses it (p. 56).

Celiealso obeys her husband's children. It can be seen from her reaction every time her stepchildren ask her to do everything. She just obeys them and lets them run over her and does whatever they ask her to do.

Mr. children all bright but they mean. They sayCelie, I want dis. Celie, I want dat. Our Mama let us have it. He don't say nothing. They try to get his tention, he hide hind a puff of smoke. Don't let them run over you, Nettie say. You got to let them know who got the upper hand They got it, I say. But she keep on, You got to fight. You got to fight. But I don't know how to fight. All I know how to do is stay alive (p.17).

As a sister, Nettie is the one that always remindsCelie to fight. Celie cannot just let them run over her. However, Celie is not willing to fight for herself. For her, it is enough to stay alive rather than to fight back.
Celie's unwillingness to fight back reminds Sofia, Harpo's wife, about her mother. For Sofia, Celie looks similar her mother who never stands up for herself. Sofia's mother always lives under her husband's foot that always does everything that her husband asks her to do (p. 38).

\section{Unattractive}

Throughout the story, Celie is described as an unattractive woman. Her personal description shows how unattractive she is. Her appearances in the story, such as wearing a tight dress and having a fat body (p.12) show that she is a very unattractive woman. Compared to Nettie, Celie is less attractive than her. "I know I'm not as pretty or as smart as Nettie, but she say I ain't dumb" (p. 11). From this statement, it can be seen that Celie's thought shows that she is not as pretty and smart as her sister.

The other characters in the story often give a direct presentation or opinion about Celie, like her father, her husband, and Shug. Celie's stepfather states that Celie is ugly, "She ugly. Don't even look like she kin to Nettie," (p. 10). For him, Celie is different from Nettie, she is ugly.

Not only Celie's stepfather who thinks she is ugly but also Shug. She said that Celie is really ugly at the first time she saw her. She looks at her from head to toe and nothing looks attractive in Celie, it is clearly stated in the story, "She look me over from head to foot. Then she cackle. Sound like a death rattle. You sure is ugly, she say, like she ain't believed it," (p. 42).

In the story, Celie's husband described Celie as an unattractive woman from the very first time he saw her. He described Celie as an ugly woman since the first time he saw her (p. 9). Later, he also describes that Celie is skinny, funny, too scared to open her mouth to people, not a good cook, a pore, and black. He says everything bad about Celie (p. 176). 


\section{Oppressions Experienced by Celie}

\section{Sexual Oppression}

Celie as a woman, she is the oppressed class in patriarchal society based on Andrea Dworkin's (Madsen, 2000: 162) fundamental terms in radical feminism. The story begins with the sexual oppression done by Celie's stepfather. She experiences repeated rapes from her stepfather at the age of fourteen. As a submissive woman, she cannot fight or refuse whenever her stepfather rapes her.

You gonna do what your mammy wouldn't. First he put his thing up gainst my hip and sort of wiggle it around. Then he grab hold my titties. Then he push his thing inside my pussy. When that hurt, I cry. He start to choke me, saying You better shut up and git used to it (p. 3).

He rapes Celie many times until Celie gets pregnant twice since her mother was very busy with her children and cannot satisfy her husband's sexual desire. So, in this case,Celie is the one who replaces her mother's role to satisfy her stepfather's sexual desire. However, Celie just keeps that as a secret and never tells her mother that her stepfather rapes her. Her mother only knows that he is so kind to her.

After Celie's mother died, Celie is more oppressed by her stepfather. He forces her to marry Albert, someone whoCelie always calls as $\mathrm{Mr}_{\text {- }}$ in her letters. Actually, Albert wants to marry Nettie, Celie's sister. However, Celie's stepfather does not let him marry Nettie because Nettie is too young for Albert. Celie's stepfather sees Nettie as an educated person, he supports Nettie to get higher education and reach her dream to be a schoolteacher. Because of that reasons, as the father,he forces Celie to marry to Albert. He thinks that Celie will be a good wife if she marries with to, as what he says to Albert, "But she'll make the better wife," (p. 10).

As a submissive woman, Celie obeys her stepfather to marry the man she does not love and love her back. Celie does not have any other choices because as a black woman, she does not have any right to decide to whom she will get married.

However, after marrying Albert, Celie's life does not even change. She is more oppressed by her husband sexually. Celie's husband that always described Celie as an unattractive woman from the very first time he saw her, he only treatsCelie as a sexual object, "Mr.___am on top of me, do his business, in ten minutes us both sleep," (p. 59). Celie never feels the sexual pleasure from her husband.

\section{Non-sexual Oppression}

In the story, Celie is not only experiencing sexual oppressions, but also the non-sexual one. Her stepfather always treated her badly. Her stepfather does not allow Celie for getting an education. Celie stays at home and he makes Celiedo everything that a woman should do at home. She has to cook and do everything like her mom, and also satisfy his sexual pleasure (p. $3)$.

After experiencing repeated rapes by her stepfather, Celie gets pregnant and the oppression does not stop there. Later, after Celie gives birth to her babies; her stepfather takes her babies and gives them to missionaries. That Celie is not allowed to care for her babies is an oppression from her stepfather.

The other non-sexual oppression that Celie gets is violence from her stepfather and husband. They do not hesitate to beat her whether Celie does what they want or not. Moreover, Albert thinks that women are good to be beaten, as what stated here, "Harpo ast his daddy why he beat me. Mr. _ say, Cause she my wife. Plus, she stubborn.All women good for-he don't finish," (p. 22). He believes that a woman should be lower than man. A woman is the inferior and a man is the superior. A woman should obey man. He thinks that he has the power to rule and control his wife by beating her.

In this story, the relationship between Celie and the men in her family, her 
stepfather, and husband, is maintained by physical violence. It is in agreement with the second and third fundamental terms of radical feminism by Andrea Dworkin (Madsen, 2000: 162), which is the relation of men and women is maintained by means of unceasing physical violence. The main reason why her stepfather and husband use physical violence to Celie is systematic under patriarchy.

Moreover, Albert treats Celie like she is a slave. At home, she does everything that a woman should do at home, such as cleaning house, cooking, and taking care her stepchildren (p. 20). At the field, Celie also has to work in the field for hours, like what is stated here, "He wake up while I'm in the field. I been chopping cotton three hours by time he come," (p. 26).

In the society where Celie lives, it is a common situation that a woman works in the field. It can be seen from the conversation between Kate and Harpo, "Harpo, she say. Harpo the oldest boy. Harpo, don't let Celie be the one bring in all the water. You a big boy now.Time for you to help out some. Women work, he say. What? shesay. Women work. I'm a man," (p. 20).

Albert oppresses Celie more by separating her with her sister, Nettie. Albert, as the one who takes the mail out of the box, receives the letters from Nettie to Celie and never gives the letter to Celie. Albert hides all letters from Nettie to Celie, and never gives the letters to Celie. He makes Celie thinks that her sister is dead.

\section{Celie's Self-determination to Fight the Oppressions}

\section{Sexual Self-determination}

After experiencing sexual oppressions, namely repeated rapes, forced to marry a man that she does not love, and treated as a sexual object, Celie undergoes a radical change in her life. She tries to fight sexual oppressions that she experiences by using sexual self-determination. Celie's sexual self- determination can be seen from her relationship with Shug in the story.

Shug is Albert's girlfriend. While she was sick, Albert brought her home and Celie takes care of her. As a submissive woman, Celie does not get angry. It seems that Celie does not have any problems when her husband brings another woman home because Celie has loved Shug from the very first time she saw Shug's picture at the beginning of the story. Celie admires Shug so much. She directly states that Shug is the most beautiful woman she ever saw. Even, Shug is prettier than Celie'smother (p. 8).

When Shug is sick, Celie's husband brings her to the house. Nonetheless, Celie's reaction does not like any other women in common who sees her husband coming home with his lover, she does not feel angry. It is the other way around, Celie feels very happy and excited like written here, "Come on in, I want to cry. To shout. Come on in. With God help, Celie going to make you well," (p. 42). It shows how Celie is very happy and excited with Shug's arrival. She really hopes to take care of Shug. She believes she can make Shug healthier with God's help.

Even though Celie feels very happy and excited when Shug comes, Shug gives a different response to Celie. She does not feel like having any interest in Celie. She seems to hate Celie from the very first time she meets Celie. Shug thinks that Celie is an unattractive woman. Celie is just an ugly woman for her (p. 42).

Time flies, Celie and Shug get along with each other. Shug does not hate Celie anymore. They start to build a lesbian relationship

Listen, she say, right down there in your pussy is a little button that gits real hot when you do you know what with somebody. It git hotter and hotter and then it melt. That the good part. But other parts good too, she say. Lot of sucking go on, here and there, she say. Lot of finger and tongue work.Button?Finger and tongue? My face 
hot enough to melt itself. She say, Here, take this mirror and go look at yourself down there, I bet you never seen it, have you? Naw. And I bet you never seen Albert down there either (p. 69).

Having a relationship with Shug makes Celie feel what she cannot get from her husband, like sexual pleasure. Shug is the one who teaches Celie about her parts of the body that Celie does not know. Shug teaches Celie about sexual pleasure that she does not get from her husband. Celie feels sexual pleasure from Shug that she does not get from her husband. They hug and kiss and do anything like two married ladies (p. 94).

By having a lesbian relationship with Shug, Celie feels safe and comfortable. Celie can feel the freedom because whenever she stays behind Shug, no one will oppress her. Shug protects Celie from getting any nonsexual oppression like beating from Albert; she stays beside Celie so that Albert will not beat Celie. This fact is strengthened with this speech when Celie tells Shug that her husband always beats her and Shug says that she will not leave Celie until she knows that Albert will never beat his wife again,

What he beat you for? sheast. For being me and not you. Oh, Miss Celie, she say, and put her arms around me. Us sit like that for maybe half a hour. Then she kiss me on the fleshy part of my shoulder and stand up. I won't leave, she say, until I know Albert won't even think about beating you (p. 66-67).

Celie's relationship with Shug shows the sexual self-determination done by Celie. Radical feminists (Madsen, 2000: 226) state that being lesbian is a form of sexual selfdetermination. Having a lesbian relationship demonstrates that women want to release from the domination of patriarchy because it is the source of women oppression. They believe that in a lesbian relationship, there is no domination of patriarchy and no one will oppress them. In this story, Celie wants to be separated from the domination of the men in her family, like her stepfather and husband that always oppress her. Celie wants to be separated from men and removes patriarchy from her life, so she builds a lesbian relationship with Shug where there is no domination and oppression from men. The other way around, Celie feels very comfortable and safe with Shug who always protects her.

Moreover, Shug never thinks that Celie is her maid. Shug brings Celie to Memphis is to encourageCelie. She hopes Celie becomes able to stand on her feet. Shug does not make Celie feels to be oppressed by treating Celie like she is her maid.

In The Color Purple, Shug represents a character that has self-determination. Shug, as an attractive woman, always encourages Celie that she needs equality in life. Shug represents a character that could live her life without any oppression because she has freedom.

Celie can decide to start her new life by having a relationship with Shug, "My life stop when I left home, I think. But then I think again. It stop with Mr.___maybe, but start up again with Shug," (p. 72). Celie thinks that her life just stops when she got married to Albert. However, she can start her new life again after she meets Shug. This is in line with the idea of radical feminism (Wardon, 1986: 135). It said that women have to be united and have solidarity with each other. Here, for a person like Celie who experiences oppressions, she needs support from people around her, like Shug. Shug and Celie become a united. They develop solidarity with each other. Shug supports and encourages Celie that Celie needs equality.

\section{Non-sexual Self-determination}

After becoming submissive and receives non-sexual oppressions, Celie becomes able to fight any oppression that she experiences by using non-sexual self-determination. She is brave enough to make choices and decisions to pursue her freedom and decide the best for her life.

Celie starts to change after knowing that Albert is the one that hides Nettie's letters, Celiegets shocked. She becomes so mad for 
knowing that Albert hides the letters. Celie has a decision to kill him although Shug Avery does not let it happens (p.122). Celie also makes a decision about the one who will sleep with Shug Avery because Shug Avery does not let her kill Albert. Celie says to Shug Avery, "Make Albert let me sleep with you from now on, while you here, I say. And somehow or other, she do," (p. 123). Celie decides that Shug Avery should make Albert let Celiesleep with Shug Avery, and surprisingly Shug Avery does it for Celie.

Celie also shows a characteristic of someone that has self-determination by fighting the oppression that she experiences. She leaves her husband and lives in Memphis with Shug Avery (p.170). Furthermore, after deciding to leave her husband, she curses her husband by saying that he is a low down dog and his dead body just a welcome mat for Celie. As an unattractive woman that her husband always says that she is too scared to open her mouth to people Celie shows that she is brave enough to speak, she cannot become a submissive woman anymore. Celie wants to fight her husband that always oppresses her. By leaving him she could enter into a new life without oppressions (p.176).

Subsequently, Celie is also brave to express her anger toward her husband and her stepchildren. She is angry at her husband because he is the one that separates her from her sister, Nettie.Moreover, when her husband gets angry and wants to slap her, Celie reacts by jabbing her case knife to his hand. Celie also gets angry with her stepchildren because they have made her life like a hell on earth (p. 171).This fact strengthens the idea that Celie finds her selfdetermination that everyone should be granted the freedom to do anything, that does not restrict the freedom of any other individual to do anything they wish (Madsen, 2000: 24). Celie realizes that no one can prevent her from achieving her freedom, including her husband.

Even though she is always described as an uneducated, submissive, and unattractive woman in the story, but Celie has a good characteristic in her life. Celie proves that she is a strong woman. She experiences oppression for a long time; however,Celie never commits suicide or just escapes from her difficult life problem. She stays there. She endures and receives the oppression that she experiences as her fate. This good side helps Celie to find her selfdetermination. If Celie escapes from her difficult life problem without doing something, Celie might never find her selfdetermination. Celie might never fight the oppression that she experiences.

After moving to Memphis, Celie does not live dependently to Shug. Celie becomes more independent. She can support her own living economically by making pants. She starts running her business in the dining room as her factory. She gets money and employees. Moreover, Celie become more educated because she has Darlene that teaches her how to talk. After the death of her stepfather, Celie and Nettie are the ones who inherit the land, house, and store from her real father.

After Celie finds her self-determination and fights oppressions that she experiences, Celie becomes happy with her life right now like what she says in her letter to Nettie, "I am so happy. I got love, I got work, I got money, friends and time. And you alive and be home soon. With our children," (p. 183). No more men oppress her. She can live her life independently and get freedom.

Here, Celie shows a good characteristic in her life. She desires to learn everything is very strong even though she is an uneducated woman. She learns how to make pants that finally helps her to support her own living economically. When her stepfather does not allow her to go to school, Celie still keeps learning every school subjects from Nettie (p. 11). In the end of the story, she also learns how to talk from Darlene. Her desire to learn helps her to find her self-determination.

Nettie represents a character that has self-determination. Nettie and Celie are also united to encourage and develop solidarity for each other. Nettie is also the one who helps to support Celie in finding self- 
determination. Nettie as the one who gets education, Nettie always encourages Celie to fight back. She cannot be a submissive woman. However, Celie never wants to fight back before she finds her self-determination.

Nettie also proves to Celie that she has self-determination; she has a characteristic that leads her to have freedom. She is able to make choices based her own preferences. She is also working to reach her freedom.She takes actions to fight against Albert. When Nettie leaves home and she finds out that Albert is following her, at first she ignore him and walks faster. However, it still makes Albert could catch her and try to kiss her. Nettie reacts and fights him by hurting Albert (p.170).

After Celie finds her self-determination, she is able to fight and live their own life without any oppression from her stepfather and husband. This is in line with the role of radical feminism. The role of radical feminism is to offer an accurate analysis of the condition of women that angry with men that oppress them, to offer a means of women rage can be properly directed to them who oppress them and to point to a struggle that is based on self-determination (Madsen, 2000: 163). Celie's anger to the oppression that she experiences and her struggle to fight oppression is based on selfdetermination. Her anger is directed to her stepfather, her husband and her children that oppress her in the family.

\section{Conclusion}

In conclusion, The Color Purple shows that women still experience inequality in life. They get many oppressions, sexually and non-sexually. It is because women are living under the domination of patriarchal society. In a patriarchal society, women are the oppressed class. Women should be able to fight back any oppression that they experience by using self-determination, by having the ability to make choices and decision for themselves in their life. Their anger should be directed to the one who oppressed them and removes patriarchy itself from their life so that they could live their life without any oppression.

Celie, the main character of The Color Purple, proves that a woman must be able to fight any oppression whatever characteristics that she has. As a woman, Celie shows that she has to fight any oppression that she experiences by having self-determination. She proves that her finding of sexual and non-sexual selfdetermination helps her to react and fight sexual and non-sexual oppressions that she experiences, and she could live her life without any oppression.

\section{References}

Madsen, Deborah L. Feminist Theory and Literary Practice. London: Pluto Press, 2000.

Tong, Rosemarie. Feminist Thought. 3rd edition. Colorado: Westview Press, 2009.

Walker, Alice. The Color Purple. New York: Harcourt Brace Jovanovich Publisher, 1982.

Wandor, Michelene. Carry on, Understudies: Theathre and Sexual Politics. New York: Routledge\&Kegan Paul Inc, 1986. 